\title{
Teams in Small Technology-Based Firms: The Roles of Diversity and Conflict Management
}

\author{
Mauro Enrique Carozzo Todaro ${ }^{{ }^{*}}$ and Luigi Stirpe ${ }^{2}$
}

\begin{abstract}
This paper explores the effect diversity and conflict management have on the relationship between teamwork and organizational performance in small technology-based firms. The study of the relationship between these variables has involved quantitative research, with the results of the survey on 107 small Brazilian high-tech firms showing that diversity and conflict management positively moderate the relationship between teamwork and organizational performance. This means that higher levels of diversity and conflict management lead to better organizational performance. At the same time, our findings indicate that conflict management is important regardless of the level of diversity within teams. This research sheds new light on the factors for rendering teamwork more effective in this specific context.
\end{abstract}

Keywords: teamwork; diversity; conflict management; technology-based firms; innovation.

Submitted: March $4^{\text {th }} 2017$ / Approved: July $30^{\text {th }} 2017$

\section{Introduction}

Technology-based firms commercially explore and develop technological innovations (Little, 1977). Their role in today's economy is so important that many governments are relying on them for long-term economic growth (World Bank, 2015). Teamwork is particularly relevant within the context of Small Technology-Based Firms (STBFs), as the complex and dynamic environment in which these firms operate requires employees at all levels to pool their knowledge, skills and abilities to tackle daily work challenges (Mintzberg, 1992; RiolliSaltzman \& Luthans, 2001; Kanovska \& Tomaskova, 2012). Nevertheless, certain team characteristics need to be considered for teamwork to be effective (West, 2002; Riolli-Saltzman \& Luthans, 2001; Klotz, Hmieleski, Bradley, \& Busenitz, 2014).

While there is abundant research on the antecedents of effective teamwork within technology-based firms (e.g., Lechler, 2001; Hen-neke \& Lüthje, 2007; Shrader \& Siegel, 2007; Patzelt, Knyphausen-Aufseß, \& Nikol, 2008; Boone \& Hendriks, 2009; Jong, Song \& Song, 2011; Ganotakis \& Love, 2012; Nielsen \& Nielsen, 2013; Qian, Cao \& Takeuchi, 2013), it has focused mainly on the dynamics within entre-preneurial and top management teams. The archetypal team-based structure of STBFs, which is their usual approach to the organization of productive work around teams outside leadership and managerial levels, seems to have received only scant attention. Within STBFs, tea-mwork is indeed spread across all positions, involving almost every productive task (Mintzberg, 1992). This study therefore focuses on organizational-level teamwork, and it explores the role that two team facets may play in explaining the differentials in teamwork's contri-bution to business success. These characteristics are 1) team diversity, and 2) conflict management. In particular, we pose the following re-search question: What impact do team diversity and conflict mana-gement have on the relationship between the degree of teamwork and organizational performance within STBFs?
The degree of teamwork within STBFs is measured here as the proportion of employees involved in work teams. By team diversity we mean the level of knowledge and skill plurality that the members of a work team have in relation to the task they perform (Horwitz, 2005); while by conflict management we mean an approach whereby opposing views on an issue are leveraged to produce solutions shared by team members (West, 2002). Team diversity and conflict management are part of a set of key elements that are believed to be conducive to increased team and organizational performance (Qian et al, 2013).

All-in-all, from a theoretical perspective this study seeks to contribute to a deeper understanding of the characteristics making work teams more effective within innovative contexts, such as STBFs. From a practical viewpoint, the study aims to provide STBF managers with insights that may help them to build more effective teams by means of team composition and conflict management strategies.

\section{Conceptual Framework and Hypotheses}

We may understand team diversity in terms of heterogeneity in knowledge and skills among team members (Horwitz, 2005). Following the Cognitive Resource Diversity Theory (Campion, Medsker, \& Higgs, 1993; Hambrick, Cho \& Chen, 1996), this heterogeneity may benefit team performance, as team members can constructively contribute to work tasks with distinctive insights and perspectives, thus responding better to work challenges while learning from each other and enriching individual human capital with new vocabulary, cognitive patterns, and work styles.

We argue that such dynamics triggered by team diversity may be highly relevant for STBFs' overall performance in light of the importance that brainstorming and knowledge-sharing has for these firms vis-à-vis the pursuit of innovation (Hülsheger, Anderson, \& Salgado, 2009). There is evidence to support these arguments. Somech and

(1) Department of Mechanical and Industrial Engineering, State University of Maranhão, Brazil

(2) Department of Business Administration, Carlos III University of Madrid, Spain

${ }^{\star}$ Corresponding author: mauro.carozzo@uema.br 
Drach-Zahavy (2013) have found a positive association between a team's functional diversity and creativity, while Zhou, Vredenburgh, and Rogoff (2013) have found that a team's functional diversity improves its overall performance, although they could not find any relevant effect on team performance of diversity in levels of education and academic majors. Other studies have stressed that the degree of team diversity may also have an effect on hard business outcomes. For example, Valle and Avella (2003) have observed that the use of interfunctional teams (comprised of professionals from different departments) with effective leadership is positively related to customer satisfaction. More recently, Henneke and Lüthje (2007) have found that heterogeneity in the composition of entrepreneurial teams may facilitate innovation in high-tech industries.

In light of the above, we therefore expect the level of diversity in knowledge, skills, and experience within teams to have a positive impact on STBFs' performance. Specifically, we propose the following:

Hypothesis 1: Diversity among team members positively moderates the relationship between teamwork and the organizational performance of STBFs, whereby the greater the degree of team diversity, the higher organizational performance will be.

While teamwork may have a number benefits, it is not a straightforward way to organize work. In particular, there may be situations in work teams that may trigger conflicts among members, such as those related to task allocation, fair rewards, choosing the best strategy to achieve team goals, or social loafing (Wageman, 1995). We argue that team members' capacity for effectively managing conflict (i.e., reducing or resolving conflictive situations) may have an impact on the organizational performance of STBFs.

Team members may effectively manage conflict when they are able to openly discuss the alternative views forthcoming within the team (Lechler, 2001). Such discussion may engender higher levels of information flows and other resources among team members (Chuang, Chen, \& Chuang., 2013), reinforce cohesion, build trust within the team (Chou \& Yeh, 2007), and ultimately facilitate the adoption of collective and more effective solutions (West, 2002). By openly addressing conflicts, team members may also foster the creation of shared mindsets and languages within the team. These may be defined as similar (and often tacit) sets of knowledge and symbols, as well as attitudes and beliefs, which facilitate decision-making and the coordination of behaviors without the need to formally communicate (Cannon-Bowers \& Salas, 2001). In the long-term, such models and languages may drive improved teamwork processes and organizational effectiveness (Schmidtke \& Cummings, 2017).

The high pressure and dynamic contexts characterizing STBFs may render team conflicts inevitable in these firms. Conflict management may therefore be a critical facilitator of teamwork's influence on organizational performance. This argument receives some empirical support from Lechler (2001), who has found that outcomes such as customer satisfaction and efficiency are positively related to conflict management within the entrepreneurial teams of German technology-based firms. Thus, we propose the following:

Hypothesis 2: Conflict management in teams positively moderates the relationship between teamwork and the organizational performance of STBFs, whereby the greater the degree of conflict management, the higher organizational performance will be.

Within-team conflicts may increase when there are higher degrees of diversity among members (Foo, 2011). Such conflicts may emerge when members, by virtue of their idiosyncrasies, disagree on issues related to the assigned tasks, goals, decision-making areas, or work methods. Pelled, Eisenhardt, and Xin (1999) have indeed found that team diversity increases cognitive conflict among team members. For example, the members of a production department may have very different perspectives on a given issue to those held by the marketing department due to their distinctive reference framework. We therefore argue that conflict management may become more relevant as a facilitator of the effect of teamwork on organizational performance when the degree of diversity among team members increases. We therefore propose the following hypothesis:

Hypothesis 3: The moderating effect of conflict management on the relationship between teamwork and organizational performance will be stronger when teams have a greater degrees of diversity among team members.

Figure 1. depicts the research model in this study.

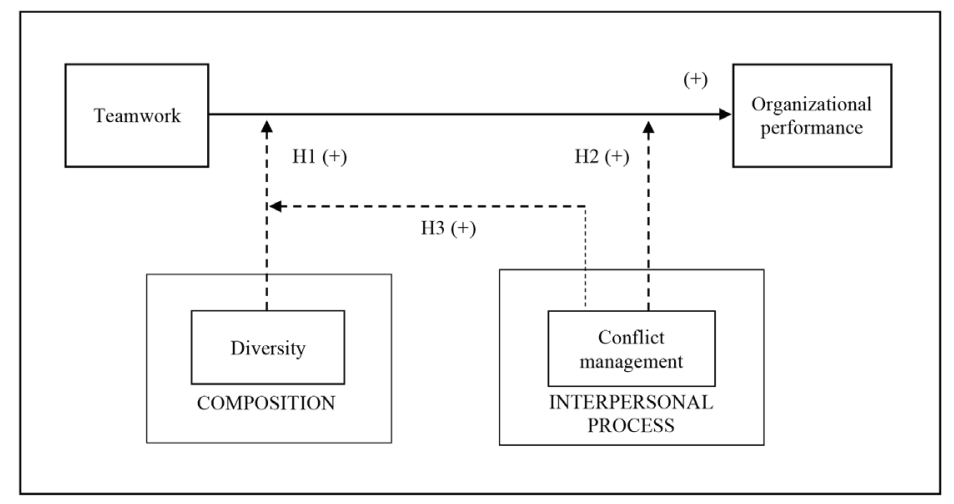

Figure 1. The proposed research model 


\section{Methodology}

\subsection{Type of research and participants}

This study is a quantitative survey-type research. The population sample consists of STBFs in Brazil with fewer than 50 employees (consistent with the definition of small firms provided by the European Commission, Instituto Brasileiro de Geografia e Estatística - IBGE and Serviço Brasileiro de Apoio às Micro e Pequenas Empresas - SEBRAE), with more than three years of market participation (Andries \& Debackere, 2007), and independently owned. The final sample includes 107 such companies (for a return rate of $18 \%$ ), of which $56 \%$ belong to the high-technology service industry, $24 \%$ to the advanced manufacturing industry, $10 \%$ to the biotechnology industry, $6 \%$ to the chemical industry, and $4 \%$ to other industries.

\subsection{Procedures and data collection techniques}

Companies were contacted by phone to communicate the purpose of the study, request an e-mail address for sending the survey, and encourage participation in the research among owners and managers. The companies contacted belonged to associations of technologybased firms, technology development centers, agencies that promote innovation and development, technology parks, or were Brazilian university spin-offs, or companies that had participated in technology innovation contests.

Data gathering involved a structured survey with closed-ended questions. This survey was sent to companies via e-mail. It contained three sections: the first one dealt with general information on the company and its context; the second one was about teamwork; and the third focused on organizational performance. We used two sources of information to define the items corresponding to each section: a) a review of the literature on teamwork and organizational performance, and b) exploratory interviews and discussions with owners and executives from different STBFs. An executive member of each participating company answered the survey.

\subsection{Measure}

In order to capture the degree of teamwork within each STBF, the survey asked respondents to use a seven-point scale to indicate the approximate proportion of employees- belonging to at least one work team, where $0=$ none $(0 \%)$; $1=$ few $(1-19 \%) ; 2=$ some (20-39\%); 3 = around half $(40-59 \%) ; 4=$ most (60-79\%); $5=$ almost all (80-99\%); and $6=$ all (100\%). 52.3\% of the companies indicated that all or almost all their employees belonged to at least one work team, while the rest of the companies surveyed indicated lower or significantly lower degrees of teamwork. The distribution was so asymmetrical that we dichotomized this variable (1 $=$ all or almost all employees belong to at least one work team: $0=$ otherwise).

We measured diversity by means of a three-item scale derived from Campion, Medsker, and Higgs (1993) ( $\alpha=0.702)$. An exemplary item was, "Team members have different backgrounds and experiences". Respondents used a seven-point scale to indicate the level of agreement with each item ( 1 = strongly disagree; 7 = strongly agree). To measure conflict management, we used a five-item scale adapted from that developed by Lechler (2001) for capturing conflict management among entrepreneurial teams $(\alpha=0.97)$. For example, one item from the scale was, "Disagreements between team members are frankly discussed". On a seven-point scale $(1=$ strongly disagree; $7=$ strongly agree), respondents had to indicate their level of agreement with each item.

Our dependent variable, organizational performance, is multidimensional, so we measured it through a set of financial and non-financial indicators (Ghobadian \& O’Regan, 2006). We measured the following indicators on a seven-point scale $(7=\mathrm{A}$ lot better than average in the industry; 1 = Well below average in the industry), and therefore selected the following: innovation (three items); flexibility (three items); quality (three items); profitability (three items); and customer satisfaction (three items). The items were adapted from Escribá-Esteve, Sánchez-Peinado and Sánchez-Peinado (2008), Ghobadian and O'Regan (2006), and Henneke and Lüthje (2007). The variable organizational performance corresponds to the mean of the scores in each one of these 15 items $(\alpha=0.82)$.

We considered the following variables as controls: industry (Shrader \& Siegel, 2007), years of operation (Delarue, Van Hootegem, Procter, \& Burridge, 2008), headcount (Delarue et al., 2008), initial sales level (Doutriaux, 1992), and government orientation (Doutriaux, 1992).

\section{Results}

Table 1. shows the descriptive statistics for the variables in the study.

\begin{tabular}{|c|c|c|c|c|c|c|c|c|c|c|}
\hline \multicolumn{2}{|c|}{ Variables } & \multirow{2}{*}{$\begin{array}{c}\text { Mean } \\
0.780\end{array}$} & \multirow{2}{*}{$\begin{array}{l}\text { SD } \\
0.419\end{array}$} & \multirow{2}{*}{$\frac{1}{-}$} & \multirow[t]{2}{*}{2} & \multirow[t]{2}{*}{3} & \multirow[t]{2}{*}{4} & \multirow[t]{2}{*}{5} & \multirow[t]{2}{*}{6} & \multirow[t]{2}{*}{7} \\
\hline 1 & Teamwork & & & & & & & & & \\
\hline 3 & Conflict management & 4.475 & 1.714 & $0.581^{\star *}$ & $0.517^{\star *}$ & - & & & & \\
\hline 5 & Years of operation & 11.630 & 7.454 & 0.036 & 0.049 & 0.146 & 0.013 & - & & \\
\hline 6 & Number of employees & 17.190 & 15.748 & $0.195^{\star}$ & 0.137 & $0.268^{\star *}$ & -0.022 & $0.411^{\star *}$ & - & \\
\hline
\end{tabular}

Table 1. Descriptive statistics 
To test the research hypotheses, we performed OLS analyses, with the results shown in Table 2.

\begin{tabular}{|c|c|c|c|c|c|}
\hline & \multicolumn{5}{|c|}{ Organizational performance } \\
\hline & Model 1 & Model 2 & Model 3 & Model 4 & Model 5 \\
\hline Chemical industry & -0.367 & -0.132 & -0.122 & -0.091 & -0.134 \\
\hline Advanced Manufacturing industry & 0.18 & 0.193 & 0.231 & 0.244 & 0.240 \\
\hline Biotechnology industry & $-0.477^{\star}$ & -0.451 & -0.425 & -0.382 & -0.474 \\
\hline Other industries & -0.089 & -0.034 & -0.064 & -0.034 & -0.027 \\
\hline Years of operation & 0.006 & 0.003 & 0.002 & 0.001 & 0.003 \\
\hline Headcount & -0.005 & -0.006 & -0.005 & -0.005 & -0.005 \\
\hline Initial sales level & $0.259^{*}$ & $0.243^{*}$ & $0.230^{*}$ & $0.224^{*}$ & $0.241^{*}$ \\
\hline Government orientation & -0.015 & 0.004 & -0.007 & -0.004 & -0.017 \\
\hline Teamwork & $0.416^{*}$ & 0.079 & 0.133 & 0.214 & 0.343 \\
\hline Diversity & & -0.017 & -0.131 & 0.044 & 0.015 \\
\hline Conflict management & & 0.140 & $0.186^{*}$ & -0.021 & 0.281 \\
\hline Teamwork $\times$ Diversity & & & $0.195^{*}$ & & 0.000 \\
\hline Teamwork $\times$ Conflict management & & & & $0.229^{*}$ & -0.128 \\
\hline Diversity $\times$ Conflict management & & & & & 0.088 \\
\hline Teamwork $\times$ Diversity $\times$ Conflict management & & & & & -0.024 \\
\hline$\Delta \mathrm{R} 2$ & & 0.039 & 0.029 & 0.029 & 0.043 \\
\hline R2 adjusted & 0.063 & 0.086 & 0.110 & 0.109 & 0.096 \\
\hline F & 1.780 & $1.902^{*}$ & $2.077^{\star}$ & $2.069^{*}$ & 1.745 \\
\hline
\end{tabular}

${ }^{a}$ Reference industry: High-technology services

${ }^{\star *} p<0.01 ;{ }^{*} p<0.05$

Table 2. Results of the regression analyses

Model 1 includes only the controls and the variable teamwork, while Model 2 also includes diversity and conflict management. The results in Model 2 indicate that only the control variable "Initial sales level" was significant.

We introduced the interaction between teamwork and diversity in Model 3. As shown, this interaction is positive and statistically significant. Hypothesis 1 is therefore supported. Figure 2 illustrates the effects this interaction has on organizational performance.
Figure 2. Effects of the interaction between teamwork and diversity on organizational performance.

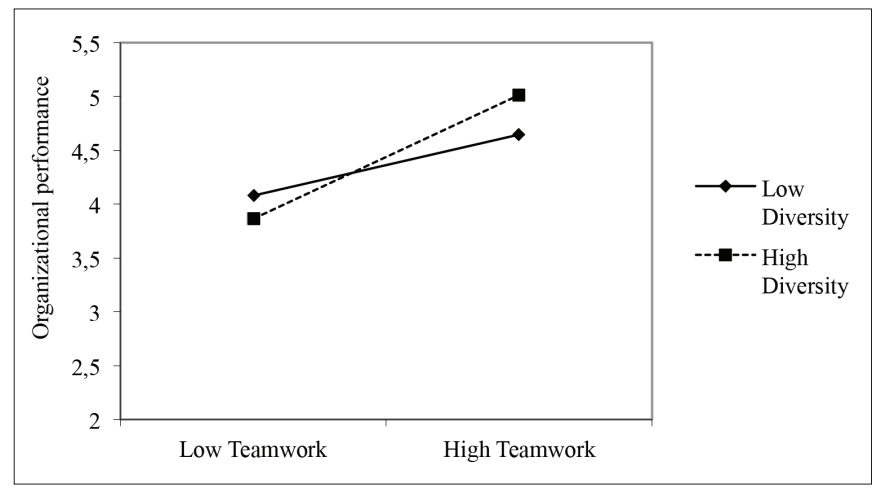

Model 4 includes the interaction between teamwork and conflict management. The regression coefficient for this interaction is positive and statistically significant, thus supporting our second hypothesis. Figure 3 plots these results. 
Figure 3. Effects of the interaction between teamwork and conflict management on organizational performance

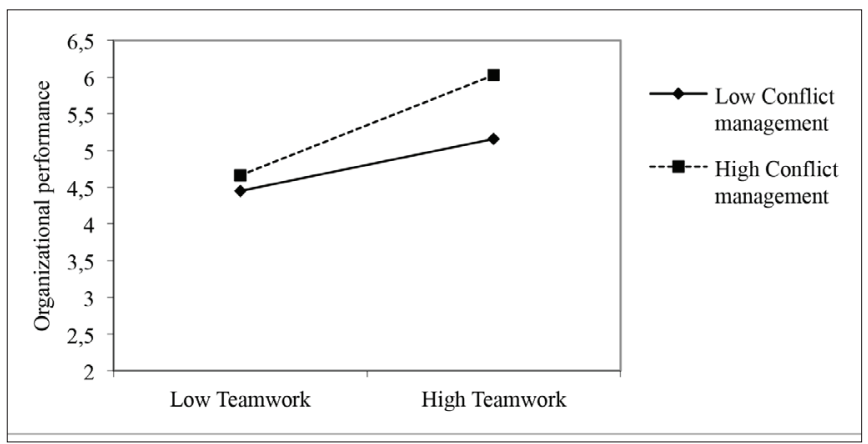

Finally, we introduced the triple interaction between teamwork, diversity, and conflict management in Model 5. As Table 2 shows, this interaction was not statistically significant, and does not therefore support hypothesis 3 .

It is worth mentioning that despite the high correlations between some of the variables in the study, the VIF values are well below 10, suggesting that multicollinearity is not a serious issue in our analyses (Hair, Black, Babin, \& Anderson, 2010).

\section{Conclusion}

This study has used a survey-type research method to provide a more detailed analysis on the way teamwork contributes to organizational performance, consistent with the call made by West, Brodbeck, and Richter (2004), Delarue et al. (2008) and, more recently, Klotz et al. (2014). In particular, our empirical analysis suggests that team diversity and conflict management may be critical drivers of teamwork effectiveness in the context of STBFs. However, contrary to what we anticipated, conflict management does not seem to acquire more importance as a driver of teamwork outcomes on organizational performance in more diverse team environments. In other words, this result suggests that conflict management may play a similar (beneficial) role regardless of the degree of team diversity. Therefore, teams with low degrees of diversity should also attend to conflict management if they are to perform better.

From a more practical perspective, this study provides STBF managers with some insight on the kind of teams they should build and nurture. First of all, they should avoid team homogeneity by choosing team members with distinctive skills and competencies. Furthermore, they should pay special attention to the way within-team conflicts are managed. Teams that manage to reduce or resolve conflictive situations do indeed seem to favor organizational performance. STBF managers may therefore be interested in providing the members of teams in their firms with the necessary training to tackle conflictive situations in a timely and constructive manner.

This study is not without its limitations; one of which is sample size, as it may limit the generalizability of the findings. Nevertheless, the response rate of $18 \%$ in this research is similar to that in previous studies (e.g., Boone and Hendrix, 2009), and in line with the $17 \%$ trend that
Cycyota and Harrison (2006) report in their meta-analysis. A second limitation involves the cross-sectional nature of the data, which calls for caution when interpreting causal relationships, as there may be potential reverse causality between our dependent and independent variables. Furthermore, as the data come from a single source (i.e., an executive member of each STBF in the sample), there is a potential threat of common method bias (Podsakoff, MacKenzie, Lee, \& Podsakoff, 2003). A final limitation is the fact that the data are limited to the Brazilian context. As the effect of work practices may depend upon the socio-institutional context (Yalabik, Chen, Lawler, \& Kim, 2008), this research cannot be extrapolated to STBFs outside Brazil.

Future research may address these issues and extend our analysis to include other moderators of the teamwork-organizational performance relationship in the STBF context. For example, some of these moderators may be related to internal team organization (e.g., level of team member interdependence, and relative level of team autonomy), as well as to interpersonal processes among team members (coordination intensity, degree of cooperation, and member commitment).

There is certainly a great deal of research to be carried out to fully understand the teamwork-organizational performance link within STBFs, and we hope that our study will inspire further work in this direction.

\section{References}

Andries, P., \& Debackere, K. (2007). Adaptation and Performance in New Businesses: Understanding the Moderating Effects of Independence and Industry. Small Business Economics, 29, 81-99. http://dx.doi.org/10.1007/s11187-005-5640-2

Boone, C., \& Hendriks, W. (2009). Top Management Team Diversity and Firm Performance: Moderators of functional-background and locus-of-control diversity. Management science, 25(2), 165-180. http://dx.doi.org/10.1287/mnsc.1080.0899

Campion, M., Medsker, G., \& Higgs, A. (1993). Relations between work group characteristics and effectiveness: implications for designing effective work groups. Personnel Psychology, 46, 823-850. http://dx.doi.org/10.1111/j.1744-6570.1993.tb01571.x

Cannon-Bowers, J.A., \& Salas, E. (2001). Reflections on shared cognition. Journal of Organizational Behavior, 22(2), 195-202. http://dx.doi.org/10.1002/job.82

Chou, H. W., \& Yeh, Y. J. (2007). Conflict, conflict management, and performance in ERP teams. Social Behavior and Personality: An International Journal, 35(8), 1035-1048. https://doi.org/10.2224/sbp.2007.35.8.1035

Chuang, C. H., Chen, S. J., \& Chuang, C. W. (2013). Human resource management practices and organizational social capital: The role of industrial characteristics. Journal of Business Research, 66(5), 678687. https://doi.org/10.1016/j.jbusres.2012.04.002 
Cycyota, C. S., \& Harrison, D. A. (2006). What (not) to expect when surveying executives. A meta-analysis of top manager response rates and techniques over time. Organizational Research Methods, 9(2), 133-160. http://dx.doi.org/10.1177/1094428105280770

Delarue, A., Van Hootegem G., Procter, S., \& Burridge, M. (2008). Teamworking and organizational performance: a review of surveybased research. International Journal of Management Reviews, 10(2), 127. http://dx.doi.org/10.1111/j.1468-2370.2007.00227.x

Doutriaux, J. (1992). Emerging High-Tech Firms: How Durable Are Their Comparative Start-Up Advantages? Journal of Business Venturing, 7(4), 303-322. https://doi.org/10.1016/0883-9026(92)90004-B

Escribá-Esteve, A., Sánchez-Peinado, L., \& Sánchez-Peinado, E. (2008). Moderating Influences on the Firm's Strategic OrientationPerformance Relationship. International Small Business Journal, 26(4), 463-489.

Foo, M. D. (2011). Teams developing business ideas: how member characteristics and conflict affect member-rated team effectiveness. Small Business Economics, 36(1), 33-46. http://dx.doi.org/10.1007/ s11187-009-9176-8

Ganotakis, P., \& Love, J. H. (2012). Export propensity, export intensity and firm performance: The role of the entrepreneurial founding team. Journal of International Business Studies, 43, 693-718. http://dx.doi.org/10.1057/jibs.2012.16

Ghobadian, A., \& O’ Regan, N. (2006). The Impact of Ownership on Small Firm Behaviour and Performance. International Small Business Journal, 24(6), 555-586. https://doi.org/10.1177/0266242606069267

Hair, J. F., Black, W.C., Babin, B. J., \& Anderson, R. E. (2010). Multivariate Data Analysis: A Global Perspective. (7th ed.), Upper Saddle River, NJ: Pearson Education.

Hambrick, D. C., Cho, T. S., \& Chen, M. J. (1996). The influence of top management team heterogeneity on firms' competitive moves. Administrative science quarterly, 41(4), 659-684. http://dx.doi.org/10.2307/2393871

Henneke, D., \& Lüthje, C. (2007). Interdisciplinary heterogeneity as a catalyst for product innovativeness of entrepreneurial teams. Creativity and innovation management, 16(2), 121. http://dx.doi.org/10.1111/j.1467-8691.2007.00426.x

Horwitz, S. K. (2005). The compositional impact of team diversity on performance: Theoretical considerations. Human Resource Development Review, 4(2), 219-245. https://doi.org/10.1177/1534484305275847

Hülsheger, U. R., Anderson, N., \& Salgado, J. F. (2009). Team-level predictors of innovation at work: A comprehensive meta-analysis spanning three decades of research. Journal of Applied Psychology, 94, 1128-1145. https://doi.org/10.1037/a0015978
Jong, A., Song, M., \& Song, L. Z. (2011). How lead founder personality affects new venture performance: The mediating role of team conflict. Journal of Management, 20(10), 1-17. https://doi. org/10.1177/0149206311407509

Kanovska, L., \& Tomaskova, E. (2012). Interfunctional coordination at hi-tech firms. Engineering Economics, 23(1), 70-76. http://dx.doi. org/10.5755/j01.ee.23.1.1224

Klotz, A. C., Hmieleski, K. M., Bradley, B. H., \& Busenitz, L. W. (2014). New venture teams: a review of the literature and roadmap for future research. Journal of Management, 40(1), 226-255. https://doi. org/10.1177/0149206313493325

Lechler, T. (2001). Social Interaction: a determinant of entrepreneurial team venture success. Small Business Economics, 16(4), 263-278. http://dx.doi.org/10.1023/A:1011167519304

Little, A.D. (1977). New technology-Based Firms in the United Kingdom and the Federal Republic of Germany. Wilton House, London. Mintzberg, H. (1992). Structure in Five: designing Effective Organizations. Prentice Hall.

Nielsen, B. B., \& Nielsen, S. (2013). Top management team nationality diversity and firm performance: A multilevel study. Strategic Management Journal, 34(3), 373-382. http://dx.doi.org/10.1002/smj.2021

Patzelt, H., Knyphausen-Aufse, D., \& Nikol, P. (2008). Top Management Teams, Business Models, and Performance of Biotechnology Ventures: An Upper Echelon Perspective. British Journal of Management, 19(3), 205-221. http://dx.doi.org/10.1111/j.14678551.2007.00552.x

Pelled, L., Eisenhardt, K., \& Xin, K. (1999). Exploring the black box: An analysis of workgroup diversity, conflict, and performance. Administrative Science Quarterly, 44(1), 1-28. https://doi. org/10.2307/2667029

Podsakoff, P. M., MacKenzie, S. B., Lee, J. Y., \& Podsakoff, N. P. (2003). Common method biases in behavioral research: a critical review of the literature and recommended remedies. Journal of Applied Psychology, 88(5), 879. http://dx.doi.org/10.1037/0021-9010.88.5.879

Qian, C., Cao, Q., \& Takeuchi, R. (2013). Top management team functional diversity and organizational innovation in China: The moderating effects of environment. Strategic Management Journal, 34(1), 110-120. http://dx.doi.org/10.1002/smj.1993

Riolli-Saltzman, L., \& Luthans, F. (2001). After the bubble burst: How small high-tech firms can keep in front of the wave. The Academy of Management Executive, 15(3), 114-124. http://dx.doi.org/10.5465/ AME.2001.5229655

Schmidtke, J. M., \& Cummings, A. (2017). The effects of virtualness on teamwork behavioral components: The role of shared mental models. Human Resource Management Review. Forthcoming. 
Shrader, R., \& Siegel, D. S. (2007). Assessing the Relationship between Human Capital and Firm Performance: Evidence from TechnologyBased New Ventures. Entrepreneurship Theory and Practice, 31(6), 893-908. http://dx.doi.org/10.1111/j.1540-6520.2007.00206.x

Somech, A., \& Drach-Zahavy, A. (2013). Translating Team Creativity to Innovation Implementation: The Role of Team Composition and Climate for Innovation. Journal of Management, 39(3), 684-708. https://doi.org/10.1177/0149206310394187

Valle, S., \& Avella, L. (2003). Cross-functionality and leadership of the new product development teams. European Journal of Innovation $\mathrm{Ma}$ nagement, 6(1), 32-48. https://doi.org/10.1108/14601060310456319

Wageman, R. (1995). Interdependence and group effectiveness. Administrative Science Quarterly, 40(1), 145-180. http://dx.doi.org/10.2307/2393703

West, M. A. (2002). Sparkling Fountains or Stagnant Ponds: An Integrative Model of Creativity and Innovation Implementation in Work Groups. Applied psychology, 51(3), 355-424. http://dx.doi.org/10.1111/1464-0597.00951
West, M. A., Brodbeck, F. C., \& Richter, A. W. (2004). Does the 'romance of teams' exist? The effectiveness of teams in experimental and field settings. Journal of Occupational and Organizational Psychology, 77(4), 467-473. http://dx.doi.org/10.1348/0963179042596450

World Bank. (2015). Exportaciones de productos de alta tecnología. Retrieved from: http://data.worldbank.org/indicator/TX.VAL.TECH.CD

Yalabik, Z. Y., Chen, S. J., Lawler, J., \& Kim, K. (2008). High-Performance work system and organizational turnover in East and Southeast Asian countries. Industrial Relations, 47(1), 145-152. http:// dx.doi.org/10.1111/j.1468-232X.2008.00509.x

Zhou, W., Vredenburgh, D., \& Rogoff, E. G. (2013). Informational diversity and entrepreneurial team performance: moderating effect of shared leadership. International Entrepreneurship and Management Journal, 11(1), 39-55. http://dx.doi.org/10.1007/s11365-013-0274-3 